\title{
Endometrial stromal cells exhibit a distinct phenotypic and immunomodulatory profile
}

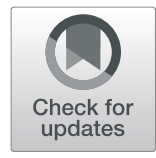

Suzanna Queckbörner ${ }^{1^{*}} \mathbb{D}$, Elisabeth Syk Lundberg ${ }^{2}$, Kristina Gemzell-Danielsson ${ }^{1}$ and Lindsay C. Davies ${ }^{3}$

\begin{abstract}
Background: In Asherman's syndrome (AS), intrauterine scarring and fibrotic adhesions lead to menstrual disorders, pregnancy loss, or infertility. A few clinical trials have piloted cell therapy to overcome AS. Understanding the role of the stromal compartment in endometrial regeneration remains poorly understood. We hypothesize that endometrial stromal cells (eSCs) represent a relevant cell population to establish novel cell-based therapeutics for endometrial disorders. The aim of this study was to characterize eSCs and evaluate their immune-cell interactions.

Methods: eSCs were isolated from healthy donors, during the proliferative stage of the menstrual cycle. Cells were characterized for expression of mesenchymal stromal cell (MSC) markers and assessed for their tumorigenic potential. eSCs were co-cultured with interferon $y$ and tumor necrosis factor $a$, and cell surface expression of their respective receptors and human leukocyte antigen (HLA) I and II determined by flow cytometry. Secreted levels of key immunomodulatory factors were established. eSCs were cultured with activated peripheral blood mononuclear cells, and T cell differentiation and proliferation determined.

Results: eSCs demonstrated an MSC surface phenotype and exhibited multipotency. Expanded eSCs retained chromosomal stability and demonstrated no tumorigenicity. Upon stimulation, eSCs licensed to an antiinflammatory phenotype with upregulated secretion of immunomodulatory factors. Stimulated eSCs did not express HLA class II. eSCs suppressed the proliferation and activation of CD4+ T cells, with the eSC secretome further downregulating central memory T cells and upregulating effector memory (EM) cells.
\end{abstract}

Conclusions: Differential responsiveness to inflammation by eSCs, compared to other MSC sources, demonstrates the need to understand the specific functional effects of individual stromal cell sources. A lack of HLA class II and triggering of EM T cell differentiation strongly links to innate in vivo roles of eSCs in tissue repair and immune tolerance during pregnancy. We conclude that eSCs may be an ideal cell therapy candidate for endometrial disorders.

Keywords: Endometrium, Stroma, Immunomodulation, Cell therapy, T cell, Asherman's syndrome, Inflammation, Infertility, Mesenchymal stromal cell

\section{Background}

Healthy endometrium regenerates approximately 450 times in a women's reproductive life without the formation of scar tissue [1]. The endometrium makes up the inner lining of the uterus with 2 distinct layers, the basalis and the transient functionalis. In a hormonally regulated 28-day cycle, the functional layer proliferates, differentiates, secretes, disintegrates, and repairs following menses. It has been

\footnotetext{
* Correspondence: suzanna.queckborner@ki.se

'Department of Women's and Children's Health, Division of Obstetrics and Gynecology, Karolinska Institutet, and Karolinska University Hospital, S-171 64 Solna, Sweden

Full list of author information is available at the end of the article
}

hypothesized that this process of endometrium regeneration is orchestrated, in part, by an endometrial progenitor cell population [2,3]. Deregulation of this cycle is seen in endometrial pathologies such as Asherman's syndrome (AS), where patients can suffer from endometrial scarring, fibrosis, and adhesions occluding the uterine cavity [4].

The menstrual cycle and its 3 main stages, menstruation and the proliferative and secretory phases, have been likened to the phases of wound repair [5-7]. Classical wound healing, as seen in the dermis, is accompanied by the formation of tissue granulation and scar maturation [8]. However, in healthy endometrium, no

(c) The Author(s). 2019 Open Access This article is distributed under the terms of the Creative Commons Attribution 4.0 International License (http://creativecommons.org/licenses/by/4.0/), which permits unrestricted use, distribution, and 
scarring is observed, suggesting regenerative healing, more akin to the fetal-like response seen in the buccal mucosa of the oral cavity [9-12].

The stromal compartment makes up the largest proportion of the endometrium and controls tissue proliferation, remodeling, and breakdown during the menstrual cycle, under the tight regulation of estrogen and progesterone, and local and peripheral immune cells [13]. Immune cell activation, abundance, and distribution vary throughout the menstrual cycle. Earlier research has investigated how the immune-profile of macrophage, neutrophil, T cell, and NK cell compartments change in the context of menses, pregnancy, and to a lesser extent healthy endometrial regeneration [14-17]. Flynn et al. [17] demonstrated that the frequency and ratio of $\mathrm{T}$ cell subsets differs during the proliferative and secretory phases of the menstrual cycle, suggesting dynamic immune-stromal cell relationships in tissue homeostasis [17]. However, few human studies have sought to further explore stromal-immune cross-talk, a factor demonstrated to be of central importance in the context of stromal cell therapies, and in the context of tissue regeneration, where the presumed mechanism of action is modulation of the local immune environment [18].

Endometrial research to date has primarily focused on factors regulating embryo implantation, emphasizing the importance of decidualization and placentation in fertility and pregnancy success. Understanding of the endometrial stromal compartment's role in regeneration after menstrual shedding remains scarce. Further knowledge will be critical in developing a better biological understanding of benign, fibrotic gynecological diseases such as AS and endometriosis, with the aim of developing suitable therapies. Cell therapy has been a steadily expanding field with 327 active clinical trials, registered with clinicaltrials.gov (as of October 28, 2019), involving "mesenchymal cells." These cell products have been primarily developed to alleviate diseases with pro-inflammatory components, or a need to repair damaged tissue. This growing trend towards cell therapeutics has now been proposed and piloted for endometrial restoration [19-23].

In the last 10 years, stromal cells derived from menstrual blood (menSCs) and umbilical cord (UC MSCs) have been piloted as a cell therapy for infertility and AS (reviewed [23]). These pilot studies have provided promising results, with increased endometrial thickness (an established measurement of responsiveness to therapy) and temporarily resumed menstruation [21, 24]. With the development of cellular therapeutics, especially within the area of MSC therapies, there has been increasing recognition of the need to understand the mechanism of action of heterogeneous cell sources and to move away from the concept of "one cell fits all," thereby acknowledging the tissue of origin when establishing a therapeutic. This is exemplified with recent single-cell RNA-sequencing studies showing that decidualized endometrial stromal cells have a specific gene expression and immune cell modulation relative to their tissue origin [25]. Equally, although MenSCs are of endometrial origin, their immune phenotype has been suggested to be more inflammatory due to the phenotypic changes caused by exposure to tissue breakdown products and apoptosis [5, 26, 27]. We therefore hypothesize that healthy, proliferative phase endometrium would represent a better alternative for cell therapy development in endometrial restoration, including the treatment of AS.

The aim of this study was to provide a detailed characterization of the endometrial stromal compartment in the proliferative phase of the menstrual cycle. In the context of cell therapy, we have sought to determine whether endometrial stromal cells (herein termed eSCs) can be classified as MSCs according to the International Society of Cellular Therapy (ISCT) minimal criteria [28, 29], determine their tumorigenic potential in vitro, and establish their immunomodulatory capacity in response to pro-inflammatory signals.

\section{Methods \\ Donor material}

Endometrial samples were obtained, during the proliferative stage of the menstrual cycle, from healthy women $(n=6)$, aged $24-32$ years. The study was approved by the regional ethics committee of Karolinska Institutet, Stockholm, Sweden, and conducted in line with the Helsinki Declaration. Written informed consent was obtained from all participating women.

All donors had normal menstrual cycles (25-35 days) and were proven fertile (at least one confirmed pregnancy). Donors were examined for the absence of hormonal diseases, uterine pathologies (e.g., endometriosis, polycystic ovary syndrome and/or previous infertility records), and sexually transmitted diseases (human immune deficiency disease, Chlamydia trachomatis-DNA, and Gonococci-DNA). None of the women had used hormonal contraception or an intrauterine device for a minimum of 3 months prior to biopsy. The subject's proliferative stage (cycle day [CD] 7-9) was calculated based on their previous time of menstruation. The biopsies were obtained from the functional layer of the endometrium, without cervical dilation or local anesthesia, using a pipelle aspirator from Cooper Surgical (Trumbull, USA).

\section{Endometrial stromal cell isolation and maintenance in culture}

The biopsy was washed and finely minced in Minimum Essential Medium $\alpha$ (MEM $\alpha$; Thermo Fisher Scientific, Dreieich, Germany) with $5 \%(\mathrm{v} / \mathrm{v})$ pooled human 
platelet-lysate (Karolinska University Hospital, Huddinge, Sweden), $100 \mathrm{IU} / \mathrm{ml}$ penicillin, $0.1 \mathrm{mg} / \mathrm{ml}$ streptomycin (Thermo Fisher Scientific), and $20 \mu \mathrm{l} / \mathrm{ml}$ heparin $1000 \mathrm{IE} / \mathrm{ml}$ (APL, Stockholm, Sweden; complete media), before digesting with dispase II $(0.75 \mathrm{U} / \mathrm{ml}$; SigmaAldrich, Taufkirchen, Germany) in complete media with agitation for $45 \mathrm{~min}$ at $37^{\circ} \mathrm{C} / 5 \% \mathrm{CO}_{2}$. Isolated cells were strained through a nylon mesh $70-\mu \mathrm{m}$ cell strainer (Corning, Gothenburg, Sweden) and incubated at $37^{\circ} \mathrm{C} /$ $5 \% \mathrm{CO}_{2}$ in $1 \mathrm{X}$ TrypLE $^{\mathrm{TM}}$ Express Enzyme (Thermo Fisher Scientific) for $10 \mathrm{~min}$, followed by washing with complete media and a centrifugation $(400 \times g)$ step. Resuspended cells were plated at a density of $1 \mathrm{E}+04$ cells/ $\mathrm{cm}^{2}$ in complete media. When adherent eSCs reached confluence $(>80 \%)$, the cells were detached in TrypLE ${ }^{\mathrm{Tm}}$ and replated at the above density. All cells were checked for mycoplasma contamination using the EZ-PCR ${ }^{\mathrm{Tm}}$ Mycoplasma Test Kit (Biological Industries, Cromwell, USA) as per the manufacturer's instructions.

\section{Colony-forming unit-fibroblast capacity and growth kinetics}

The number of colony-forming unit-fibroblasts (CFU-F) relative to the number of seeded eSCs after plastic adherence and expansion for one passage was recorded. Briefly, $1 \mathrm{E}+02$ eSCs, at passage $1(\mathrm{P} 1 ; n=6)$, were seeded into 1 well of a 6-well plate. Cells were cultured in complete media for 14 days, with media changes every 3 days. Cells were washed with phosphate-buffered saline (PBS; SigmaAldrich) and fixed with $70 \%$ (v/v) ethanol (Histolab, Gothenburg, Sweden) for $60 \mathrm{~min}$, before washing with PBS and staining with $0.1 \%(\mathrm{w} / \mathrm{v})$ crystal violet (Sigma-Aldrich) dissolved in distilled water. Colonies of more than 32 cells were counted allowing exclusion of transit amplifying cells [30]. CFU-F was calculated using the below formula:

$$
\text { CFU-F }=\frac{\text { number of colonies formed }}{\text { number of cells seeded }} \times 100
$$

Growth kinetics were monitored by calculating cell population doublings (PDs) at each passage using the formula $\log n / \log 2$, where $n$ is the number of cells at harvest, divided by the number of cells seeded. The cumulative $\mathrm{PD}$, up to $\mathrm{P} 6$, was calculated to evaluate the proliferative capacity of each donor. PD rate was calculated by dividing the number of days in culture with the number of PDs recorded.

\section{Characterization of endometrial stromal cell surface markers}

The MSC phenotype of passaged cells at P3-4 was confirmed by flow cytometry as per the ISCT guidelines $(n=6)$ [28]. eSCs were detached from culture flasks using $\quad 0.05 \% \quad(\mathrm{v} / \mathrm{v})$ Trypsin-EDTA (Thermo Fisher
Scientific) and evaluated for cell surface expression of CD73, CD90, CD105, CD14, CD19, CD34, CD45, and human leukocyte antigen (HLA) I and II (see Table 1 for details of antibodies and IgG controls). LIVE/DEAD ${ }^{\mathrm{TM}}$ Fixable Aqua Dead Cell Stain Kit (Thermo Fisher Scientific) was used to assess viability. All cells were stained for 15 min in the dark at room temperature, before washing in PBS, centrifugation at $400 \times g$ for $5 \mathrm{~min}$ and resuspension in PBS/0.1\% (w/v) bovine serum albumin (BSA, SigmaAldrich) for analysis. Samples were run on a CytoflexS flow cytometer (Beckman Coulter, Bromma, Sweden) equipped with 4 lasers: $405 \mathrm{~nm}, 638 \mathrm{~nm}, 488 \mathrm{~nm}$, and 561 $\mathrm{nm}$, and 10,000 gated events recorded. Data was analyzed using FlowJo software (v10.6.1; BD, OR, USA).

\section{Osteogenic and adipogenic differentiation}

eSCs were evaluated for their multipotency by differentiating down osteogenic and adipogenic lineages using StemMACS $^{\text {тм }}$ OsteoDiff Media (Miltenyi Biotec, Bergisch

Table 1 Antibodies and Ig controls used for cell surface characterization

\begin{tabular}{|c|c|c|c|c|}
\hline $\begin{array}{l}\text { Antibodies/isotype } \\
\text { controls }\end{array}$ & Clone & Fluorochrome & Company & $\begin{array}{l}\text { Catalog } \\
\text { number }\end{array}$ \\
\hline CD90 & $5 E 10$ & PERCP Cy5.5 & Biolegend & 328117 \\
\hline CD73 & AD2 & APC & Abcam & ab155378 \\
\hline CD105 & MEM-229 & $P E$ & Abcam & ab53321 \\
\hline CD45 & $\mathrm{HI30}$ & PB & Biolegend & 304021 \\
\hline CD14 & HCD14 & PB & Biolegend & 325615 \\
\hline CD19 & HIB19 & PB & Biolegend & 302223 \\
\hline CD34 & 581 & PB & Biolegend & 343511 \\
\hline CD120a & W15099A & APC & Biolegend & 369906 \\
\hline CD120b & REA520 & PE & Miltenyi Biotec & 130107705 \\
\hline CD119 & GIR-94 & $P E$ & Biolegend & 308703 \\
\hline HLA II & CR3/43 & FITC & Dako & F0817 \\
\hline HLA I & W6/32 & AF 488 & Biolegend & 311413 \\
\hline CD3 & UCHT1 & V450 & BD Bioscience & 560365 \\
\hline CD4 & RPA-T4 & PERCP Cy5.5 & BD Bioscience & 560650 \\
\hline $\mathrm{CD} 25$ & M-A251 & $P E$ & BD Bioscience & 555432 \\
\hline $\mathrm{CD} 27$ & M-T271 & AF700 & BD Bioscience & 560611 \\
\hline CD127 & HIL-7R-M21 & AF647 & BD Bioscience & 558598 \\
\hline CD45RA & $\mathrm{HI} 100$ & PE & Biolegend & 304107 \\
\hline $\begin{array}{l}\text { Mouse } \lg G 1 \\
/ \lg G 2 \mathrm{a}\end{array}$ & & PE/FITC & BD Bioscience & 342409 \\
\hline Mouse lgG1, k & $15 \mathrm{H} 6$ & APC & Abcam & ab37391 \\
\hline Mouse $\operatorname{lgG} 1, \mathrm{k}$ & MOPC-21 & PB & Biolegend & 400131 \\
\hline Mouse $\operatorname{lgG} 1, \mathrm{k}$ & MOPC-21 & PerCP Cy5.5 & Biolegend & 400149 \\
\hline Mouse $\operatorname{lgG} 1, \mathrm{k}$ & 11711 & PE & R\&D Systems & IC002P \\
\hline Mouse lgG2a & $X 5563$ & $P E$ & Abcam & ab91363 \\
\hline
\end{tabular}

$A P C$ allophycocyanin, AF Alexa Fluor, PB Pacific Blue, FITC fluorescein isothiocyanate, $P E$ phycoerythrin, $\operatorname{PerC} P$ Cy5.5 peridinin chlorophyll protein 
Gladbach, Germany) and StemPro ${ }^{\text {Tut }}$ Adipogenesis Differentiation Kit (Thermo Fisher Scientific) respectively. Differentiation was performed according to the manufacturer's instructions. Briefly, 1E+05 eSCs at P2 were seeded in 1 well of a 12-well plate and cultured in complete media until reaching $100 \%$ confluence $(n=5)$. The cells were then cultured for 21 days with differentiation media, with media changed every 3 days. The control wells continued to be treated with complete media. Differentiation was assessed using Alizarin Red (osteogenic) and Oil Red O (adipogenic) staining.

\section{Alizarin Red staining}

Cells were washed and fixed in 10\% (v/v) formalin (Histolab) and stained with $2 \%(\mathrm{w} / \mathrm{v})$ Alizarin Red solution (Sigma-Aldrich), $\mathrm{pH} 4.1-4.3$, for $20 \mathrm{~min}$ before washing with distilled water. Cells were imaged using a Nikon Eclipse Ts 2 microscope (Nikon, Solna, Sweden) using IC Measure Software v2.0.0133 (The Imaging Source Europe, Bremen, Germany).

\section{Oil Red $O$ staining}

Cells were washed twice with PBS and fixed with $10 \%$ $(\mathrm{v} / \mathrm{v})$ formalin for $60 \mathrm{~min}$ at room temperature. Fixed cells were rinsed with distilled water and incubated with $60 \%(\mathrm{v} / \mathrm{v})$ 2-Propanol (Sigma-Aldrich) for $5 \mathrm{~min}$ at room temperature. Cells were stained with $0.6 \%(\mathrm{w} / \mathrm{v})$ Oil Red $\mathrm{O}$ (Sigma-Aldrich) for $10 \mathrm{~min}$ at room temperature before washing with distilled water.

\section{Karyotyping}

eSCs $(n=4$, P3) were karyotyped by G-banding at the Department of Clinical Genetics, Karolinska University Hospital, Solna, Sweden. eSCs were cultured to $60 \%$ confluence and treated with $10 \mu \mathrm{g} / \mathrm{mL}$ KaryoMAX ${ }^{\text {sim }}$ Colcemid $^{\text {max }}$ Solution (Thermo Fisher Scientific) for $5 \mathrm{~h}$, followed by dissociation with TrypLE ${ }^{\text {ru }}$. The cells were pelleted via centrifugation at $140 \times g$ for $10 \mathrm{~min}$, resuspended in pre-warmed hypotonic solution (1:2 $0.56 \%$ $(\mathrm{w} / \mathrm{v})$ potassium chloride: $0.6 \%(\mathrm{w} / \mathrm{v})$ sodium citrate; Sigma-Aldrich), and incubated for $10 \mathrm{~min}$ at $37^{\circ} \mathrm{C} / 5 \%$ $\mathrm{CO}_{2}$. Following centrifugation, the cells were resuspended in fixative (3:1 methanol: acetic acid; SigmaAldrich) at room temperature. Metaphase spreads were prepared on glass microscope slides and G-banded by brief exposure to $0.017 \%$ trypsin (Thermo Fisher Scientific) in PBS and stained with Gurr's/Leishmann's stain (Sigma-Aldrich). A minimum of 25 metaphase spreads were analyzed using the Metafer4 Complete Metafer System (MetaSystems, Altlussheim, Germany) with a Carl Zeiss AxioImager Z2 microscope (Carl Zeiss, Inc., Jena, Germany) and Ikaros karyotyping platform software (MetaSystems).

\section{Quantitative real-time PCR for $h$ TERT}

eSCs (P3; $n=6)$ and endometrial adenocarcinoma-derived Ishikawa cells (gifted from Cancer Center Karolinska University Hospital, Solna, Sweden) were lysed and total RNA extracted using the Quick-RNA Microprep Kit (Zymo Research, CA, USA) according to the manufacturer's instructions. RNA was reconstituted in RNase free water, and concentrations were established using the Qubit RNA HS Assay Kit (Thermo Fisher Scientific). cDNA was produced using the SuperScript ${ }^{\mathrm{m}}$ Vilo $^{\mathrm{Tm}}$ cDNA Synthesis kit (Thermo Fisher Scientific). Quantitative PCR (qPCR) was performed with the hTERT primer pair, FW: 5' GCCGTACATGCGACAGTTC3' REV: 5'TCATTCAGGGAGGAGCTCTG3' using Power SYBR $^{\circ}$ Green PCR Master Mix (Thermo Fisher Scientific) on a StepOnePlus $^{\text {tix }}$ Real-Time PCR System (Thermo Fisher Scientific) as per the manufacturer's instructions. Ribosomal protein L13a RPL13A was used as a housekeeping gene FW: 5'CCTGGAGGAGAAGAGGAAAGAGA3' REV: 5' TTGAGGACCTCTGTGTATTTGTCAA3' [31].

\section{Quantitative Telomeric Repeat Amplification Protocol (qTRAP)}

eSC telomerase activity was evaluated at P4-5 using qTRAP as previously described [12]. eSCs $(0.5 \mathrm{E}+06 ; n=$ 6) were washed in PBS, centrifuged at $500 \times g$ for $5 \mathrm{~min}$, and resuspended in $100 \mu \mathrm{l}$ Chemicon $^{\mathrm{Tx}}$ TRAPeze $^{\mathrm{Tm}} 1 \mathrm{X}$ CHAPS Lysis Buffer (EMD Millipore, Burlington, USA). Cells were incubated on wet ice for $30 \mathrm{~min}$ to ensure complete lysis. Lysates were centrifuged at $18,000 \times g$ for 20 min at $4{ }^{\circ} \mathrm{C}$ and the supernatant collected and snap frozen. A mastermix containing $5 \mu \mathrm{l}$ (equivalent of 10 , 000 cells) of cell lysate, $100 \mathrm{ng}$ of TS primer (5' AATCCGTCGAGCAGAGTT3'), $50 \mathrm{ng}$ of ACX primer (5'GCGCGG[CTTACC $]_{3}$ CTAACC-3'), $12.5 \mu \mathrm{l}$ of Fast $\mathrm{SYBR}^{\mathrm{Tn}}$ Green Master Mix, and PCR grade water was made, with a reaction volume of $20 \mu \mathrm{l}$. qTRAP was performed using a StepOnePlus ${ }^{\mathrm{Tm}}$ Real-Time PCR System, with reaction conditions of $25^{\circ} \mathrm{C}$ for $25 \mathrm{~min}, 95^{\circ} \mathrm{C}$ for $10 \mathrm{~min}$, followed by 40 cycles of $95^{\circ} \mathrm{C}$ for $15 \mathrm{~s}$ and $60^{\circ} \mathrm{C}$ for $1 \mathrm{~min}$ and $30 \mathrm{~s}$. A standard curve was run using the Ishikawa cell line $(0-10,000$ cells/reaction). Heat inactivated controls $\left(85^{\circ} \mathrm{C}, 30 \mathrm{~min}\right)$ acted as negative controls. Telomerase activity in cell lines or samples was calculated based on the threshold cycle. Data are expressed as relative telomerase expression (RTA) when compared to the Ishikawa cell control.

\section{Soft-agar tumorigenicity assay}

eSCs $(\mathrm{P} 5 ; n=5)$ were checked for neoplastic transformation capacity (anchorage independent growth) using the CytoSelect $^{\text {Tm }}$ 96-Well Cell Transformation Assay (Cell Biolabs, San Diego, USA) as per the manufacturer's instructions. Ishikawa cells were expanded under the same 
conditions and treated as a positive control for anchorage independent growth. Briefly, in a 96-well plate, a $0.6 \%(\mathrm{w} / \mathrm{v})$ base agar layer was added to the wells and allowed to solidify at $4{ }^{\circ} \mathrm{C}$ for $30 \mathrm{~min}$. The second layer of $0.4 \%(\mathrm{w} / \mathrm{v})$ agar containing eSCs or Ishikawa cells (1, 5 , and $10 \mathrm{E}+03$ cells $/ \mathrm{ml}$ ) was added and incubated at $4{ }^{\circ} \mathrm{C}$ for $15 \mathrm{~min}$. One hundred microliters of complete culture media was added to all wells, and the plate was incubated for 10 days at $37^{\circ} \mathrm{C}$ in a humidified incubator at $5 \% \mathrm{CO}_{2}$. To terminate the study and visualize the colonies, $50 \mu \mathrm{l}$ of the provided agar solubilizing solution was added to each well and the plate was incubated at $37^{\circ} \mathrm{C}$ for $60 \mathrm{~min}$. The gels were aspirated up and down using a pipette to ensure solubilization, and $25 \mu \mathrm{l}$ of the provided lysis buffer was added. Following 15 min incubation at room temperature, $10 \mu \mathrm{l}$ from each well was transferred to a 96-well black microplate (Sigma-Aldrich) for relative fluorescence unit (RFU) at $485 / 520 \mathrm{~nm}$ using a FLUOstar ${ }^{\circ}$ Omega plate reader (BMG Labtech, Germany). Cultures were assessed at time 0 (immediately after agar solidification, to determine RFU for each seeding cell number) and at day 10 .

\section{Endometrial stromal cell responsiveness to inflammatory cytokines}

eSCs $(\mathrm{P} 4 ; n=6)$ were exposed to $10 \mathrm{ng} / \mathrm{ml}$ human recombinant tumor necrosis factor alpha (TNF $\alpha$; PeproTech Nordic, Stockholm, Sweden) and $100 \mathrm{IU} / \mathrm{ml}$ interferon gamma (IFN $\gamma$; Sigma-Aldrich) for 3 and 7 days in complete media, as previously described [32]. Complete media alone served as a control. Media was changed at day 4 for the day 7 stimulations to ensure equal conditioning of the media in downstream assays. Conditioned media was collected, centrifuged at $500 \times g$ for $5 \mathrm{~min}$ to remove cellular debris, snap frozen, and stored at $-80^{\circ} \mathrm{C}$ prior to usage. The cells were detached using $0.05 \%(\mathrm{v} / \mathrm{v})$ Trypsin-EDTA and counted for normalization of data.

\section{Flow cytometry}

eSCs were stained for cell surface markers CD120a, CD120b, CD119, HLA I, and HLA II for $15 \mathrm{~min}$ at room temperature in the dark (see Table 1 for antibodies). Stained cells were washed with PBS and resuspended in PBS $/ 0.1 \%(\mathrm{w} / \mathrm{v})$ BSA for analysis. LIVE/DEAD ${ }^{\mathrm{mm}}$ Fixable Aqua Dead Cell Stain Kit was used to assess viability. Twenty thousand gated (viable cells) events were recorded using a CytoFlexS and analyzed using FlowJo software.

\section{Conditioned medium analyses}

Enzyme-linked immunosorbent assay (ELISA): Interleukin (IL)-6 was measured within the cell culture supernatant using the Human IL-6 DuoSet ELISA (R\&D Systems, Abingdon, UK) according to the manufacturer's instructions. Prostaglandin E2 (PGE2) was assessed using the Prostaglandin $E_{2}$ Parameter Assay Kit (R\&D Systems) as per the manufacturer's instructions.

Indoleamine 2,3-dioxygenase (IDO) activity was determined by measurement of L-kynurenine concentration, a terminal breakdown product of tryptophan, within the eSC-conditioned media [33, 34]. Briefly, $75 \mu \mathrm{l}$ of $30 \%$ (v/ v) trichloro-acetic acid (Sigma-Aldrich) was added to $150 \mu \mathrm{l}$ of conditioned culture media and centrifuged at $8000 \times g$ for $5 \mathrm{~min}$. The sample was combined with an equal volume of Ehrlich's reagent $(2 \% \quad[\mathrm{w} / \mathrm{v}] \quad \mathrm{p}-$ dimethylbenzaldehyde in acetic acid), and the absorbance was measured at $490 / 492 \mathrm{~nm}$ using a Varioskan ${ }^{\mathrm{Tu}}$ Flash Multimode Plate Reader (Thermo Fisher Scientific). Data were normalized to cell number.

\section{Co-culture of peripheral blood mononuclear cells and endometrial stromal cells}

Peripheral blood mononuclear cells (PBMCs; $n=2$ donors) were isolated from buffy coats as previously described [32]. Briefly, the blood was diluted with PBS and layered over Lymphoprep $^{\text {Tx }}$ (Fresenius Kabi Norge, Oslo, Norway) and centrifuged at $500 \times g$ for $30 \mathrm{~min}$. The PBMC fraction was removed, washed, and resuspended in RPMI (Thermo Fisher Scientific), 10\% (v/v) human AB serum, $100 \mathrm{IU} / \mathrm{ml}$ penicillin, and $0.1 \mathrm{mg} / \mathrm{ml}$ streptomycin. PBMCs were labeled with the CellTrace $^{\mathrm{Tm}}$ CFSE Cell Proliferation Kit (Thermo Fisher Scientific) at a working concentration of $0.25 \mu \mathrm{M}$. PBMCs were activated with anti-CD2, anti-CD3, and anti-CD28 activation beads at a 1:2 bead to cell ratio (Miltenyi Biotec). Unloaded beads served as an unstimulated control. eSCs $(n=6$; P3-4; $1 \mathrm{E}+05)$ were cultured with $1 \mathrm{E}+06$ PBMCs, either in direct contact or separated by $0.4 \mu \mathrm{m}$ polyethylene terephthalate transwells (BD Biosciences, CA, USA), for 5 days at $37^{\circ} \mathrm{C} /$ $5 \% \mathrm{CO}_{2}$. PBMCs were stained at the end of the culture period for cell surface markers CD3, CD4, CD25, CD27, and CD45RA (see Table 1 for antibodies) for $15 \mathrm{~min}$ at room temperature. Stained cells were washed with $\mathrm{PBS}$ and resuspended in PBS/0.1\% (w/v) BSA for analysis. LIVE/DEAD ${ }^{\mathrm{m}}$ Fixable Aqua Dead Cell Stain Kit was used to assess viability. Fifty thousand viable, gated events were recorded using a CytoFlexS flow cytometer and analyzed using FlowJo.

\section{Statistical analysis}

Comparisons in the groups were analyzed using one-way ANOVA with paired two-tailed $t$ test. Mann Whitney $U$ test or Wilcoxon test was used where data was nonparametric. Normality was determined by the ShapiroWilk test. Equal variance was determined by Bartlett's Test and $F$ Test when assuming Gaussian distribution. Statistical significance was assumed at $p<0.05$ (Prism 8.0; GraphPad, San Diego, CA, http://www.graphpad.com). 


\section{Results}

eSCs can be reliably isolated and expanded from healthy women

eSCs were isolated from 6 healthy, proven-fertile donors (age range 24-32), during the proliferative phase of the menstrual cycle (CD 7-9), and compared with regard to their ability to form colonies (Fig. 1a and Table 2). At P1, the average PD rate/week of the eSCs was 3.49, with a standard deviation (SD) of 1.28 (Fig. 1b). Cell yield at P1 and P2 was calculated as fold change compared to the original seeding density. At these passages, the approximate fold increase was 7 (7.42 fold at P1 and 7.1 fold at P2). This did not alter significantly between P1 and P6 (Fig. 1b). Cumulative growth kinetics supported this finding, demonstrating that all donors could be expanded for a minimum of 6 passages without entering replicative senescence (defined as 3 consecutive passages with $<0.5$ PD/week; Fig. 1c).

eSCs exhibit an MSC cell surface expression profile and show multi-lineage differentiation potential

Culture expanded eSCs were phenotypically characterized for their expression of cell surface markers CD90, CD73, CD105, CD45, CD34, CD14, CD19, HLA I, and HLA II, as per the ISCT's minimal criteria for MSC [28]. eSCs from all donors were positive for CD90, CD73, CD105, and HLA I (>95\%; Fig. 2a-c and e) and were negative for CD45, CD34, CD19, CD14, and HLA II (>2\%; Fig. 2d, f). All donors were confirmed as possessing the ability to differentiate down both osteoblastic and adipocyte lineages upon stimulation, as we have previously demonstrated [35]. Alizarin Red staining confirmed the presence of calcium deposits associated with osteogenic differentiation, and adipocyte differentiation was evidenced by the detection of lipid droplets stained red with Oil Red O. No spontaneous differentiation was seen within the control wells (Additional file 1: Figure S1).
eSCs retain chromosomal stability and demonstrate low tumorigenic potential upon in vitro expansion

eSCs at P3, the point of expansion where a therapeutic dosage for localized therapy could theoretically be generated, was karyotyped to determine chromosomal stability. All karyotypes were categorized as normal $(46, \mathrm{XX})$ with no aneuploidy, deletion/additions, or translocations (Fig. 3a). eSCs demonstrated extremely low levels of endogenous telomerase activity, with a mean RTA of $0.036 \%$ compared to Ishikawa cells. Heat inactivated controls confirmed the specificity of the reaction (Fig. 3b). These data were supported by detection of hTERT mRNA only in the Ishikawa positive control, and not in the eSCs (data not shown).

The soft agar tumorigenicity assay was utilized to investigate the potential anchorage-independent tumor forming capacity of eSCs. Tumor formation was observed within the Ishikawa positive control cultures, with the mean RFU increasing after 10 days at all 3 initial seeding densities $(1000$ cells $/ \mathrm{ml}=24.92 ; 5000$ cells $/ \mathrm{ml}=$ 182.4 and 10,000 cells $/ \mathrm{ml}=162.5$; Fig. $3 \mathrm{c}$ ). In contrast, the RFU of the eSCs did not increase relative to the original seeding density $(1000$ cells/ $\mathrm{ml}=-0.73 ; 5000$ cells/ $\mathrm{ml}=-3.32$ and 10,000 cells $/ \mathrm{ml}=-19.81$; Fig. 3c).

\section{eSCs constitutively express receptors for pro- \\ inflammatory cytokines and are responsive to anti- inflammatory licensing}

Expression of IFNy receptor (R) I (CD119) and TNFRs I (CD120a) and II (CD120b) were evaluated on the surface of eSCs. eSCs demonstrated constitutive expression of CD119 and CD120b on the cell surface, with a subpopulation of CD120b+ eSCs also expressing CD120a (mean $35.25 \% \pm$ SD 18.27\%; Fig. 4a-f). CD119 expression increased significantly following stimulation at day 3 and day 7 compared to unstimulated controls (Fig. 4g; day 3 $p=0.0086$; day $7 p=0.0085)$. No change in expression

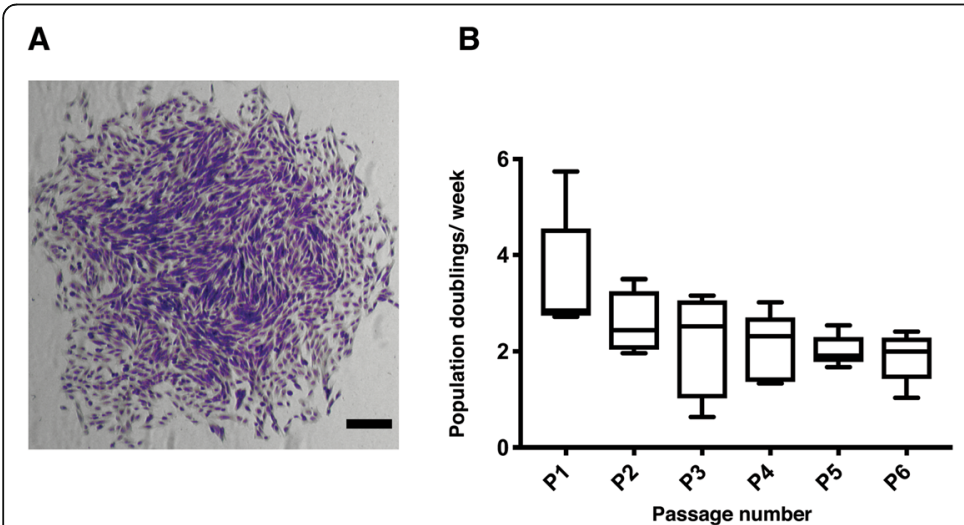

C

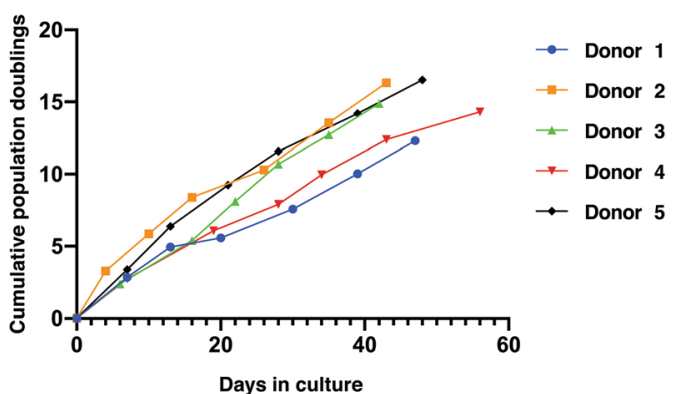

Fig. 1 Endometrial stromal cells (eSCs) can be reproducibly isolated and expanded in vitro. a Example of an eSC colony at passage (P)1, stained with crystal violet, scale bar $=100 \mu \mathrm{m}$. $\mathbf{b}$ Mean population doubling rate per week for eSCs at P1-P6. Box and whisker plots indicate minimum to maximum range ( $n=5$ donors). c Cumulative population doublings for 6 consistent passages ( $n=5$ donors) 
Table 2 Endometrial stromal cell donor information

\begin{tabular}{llllll}
\hline Donor & Cycle day & Age & \% CFU-F at P1 & Yield at P1 (fold change) & Yield at P2 (fold change) \\
\hline 1 & 7 & 29 & $15 \%$ & 5.5 & 6 \\
2 & 9 & 31 & $9 \%$ & 7.2 & 4.3 \\
3 & 8 & 31 & $19 \%$ & 9.7 & 5.9 \\
4 & 9 & 24 & $19 \%$ & 5.2 & 8.1 \\
5 & 7 & 31 & $17 \%$ & 10.3 & 8 \\
6 & 9 & 32 & $24 \%$ & 6.6 & 10.3 \\
\hline
\end{tabular}

Endometrial stromal cell (eSC) donor information including age, menstrual cycle day of cell isolation, colony forming unit-fibroblast (CFU-F), and fold change in yield of eSCs at passage (P) 1 and 2

level in response to prolonged inflammation was seen in $\mathrm{CD} 120 \mathrm{a}$ and $\mathrm{CD} 120 \mathrm{~b}$ as assessed by median fluorescence intensity (MFI; Fig. 4h, i). Cell surface levels of the constitutively expressed marker HLA I were significantly increased following stimulation at day 3 and day 7 compared to unstimulated controls (Fig. 4m; day $3 p=$ 0.0004; day $7 p=0.0241$ ). eSCs expressed no HLA class II on their cell surface, and this was maintained following stimulation for both 3 and 7 days (Fig. $4 n-p$ ).

IDO production was switched on with L-kynurenine metabolites evident within the conditioned media only after 3 and 7 days of stimulation (Fig. 4q; $p=0.0022$ ). No further increase in IDO activity was detected with prolonged (7 day) stimulation compared to 3 days (Fig. $4 q)$. IL-6 was constitutively secreted by the eSCs, with stimulation significantly increasing levels detected at days 3 and 7 compared to controls (Fig. 4r; day $3 p=0.0108$; day $7 p<0.0001)$. PGE2 was undetectable in control samples, but switched on following 3 and 7 days of stimulation (Fig. 4s; day $3 p=0.0286$; day $7 p=0.0159$ ).

\section{eSCs suppress the proliferation of CD4+ T cells and modulate their differentiation}

eSCs significantly suppressed the proliferation of CD4+ $\mathrm{T}$ cells, as assessed by proliferation index, both in direct contact and under transwell culture conditions (Fig. 5a;
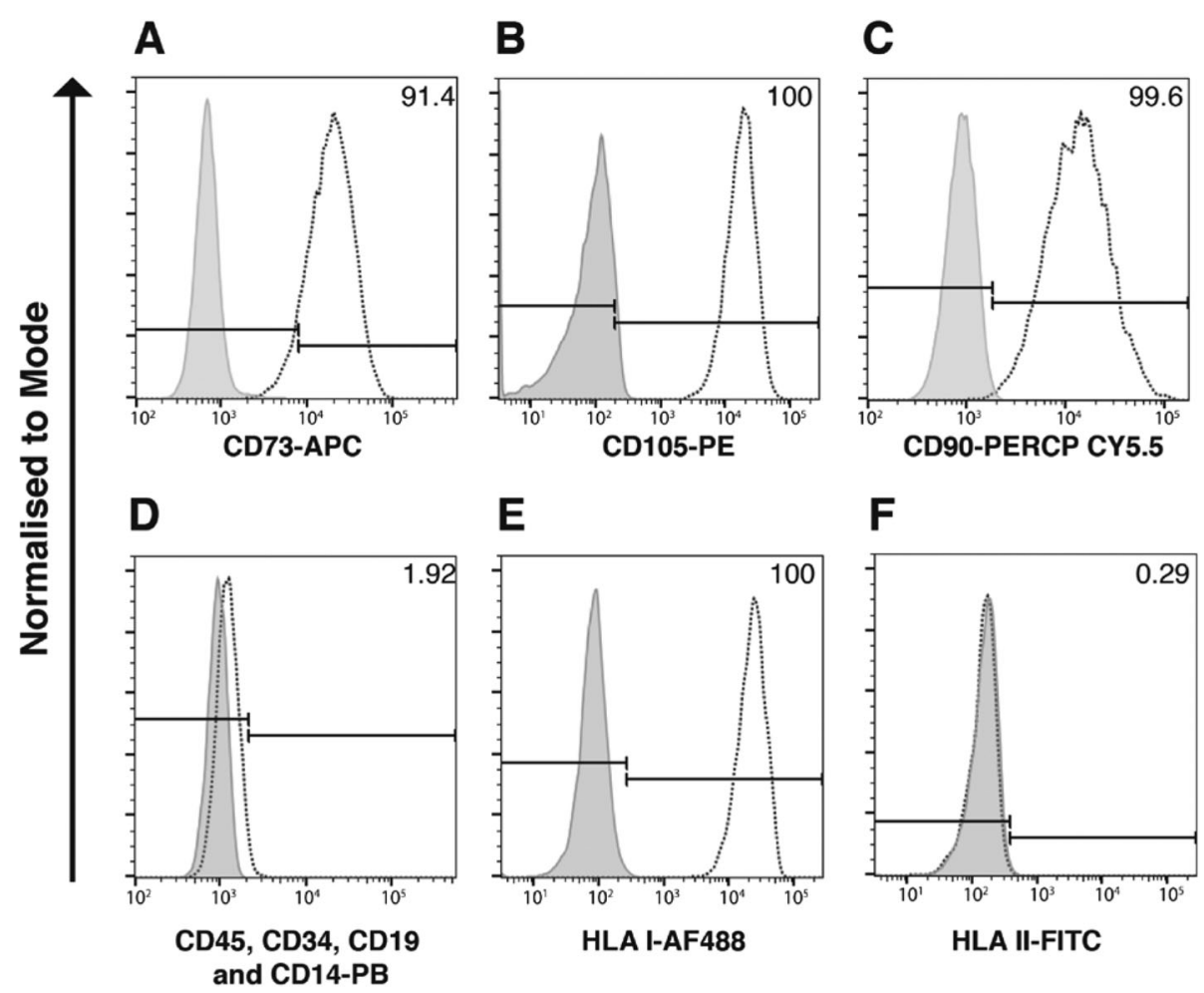

E

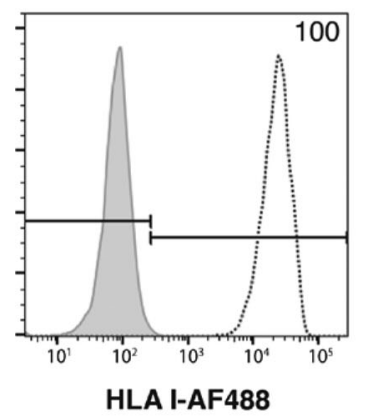

$\mathbf{F}$

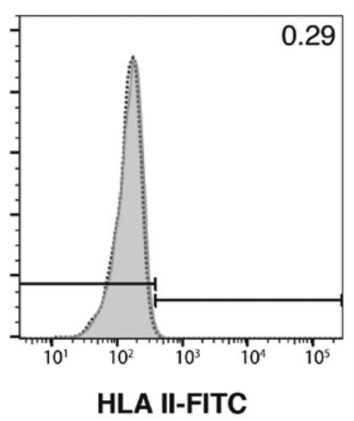

Fig. 2 Endometrial stromal cells (eSCs) express typical mesenchymal stromal cell (MSC) markers. Representational histograms (colored white) of eSC cell surface expression of a CD73 - allophycocyanin (APC); b CD105-phycoerythrin (PE); c CD90_peridinin chlorophyll protein (PerCP) -Cy5.5; d CD45, CD34, CD19, and CD14_Pacific Blue (PB); e human leukocyte antigen (HLA) I—Alexa Fluor (AF) 488; and f HLA II—fluorescein isothiocyanate (FITC; $n=6$ ) with \% of positive cells for each antigen. Gray histograms indicate respective immunoglobulin controls 
A

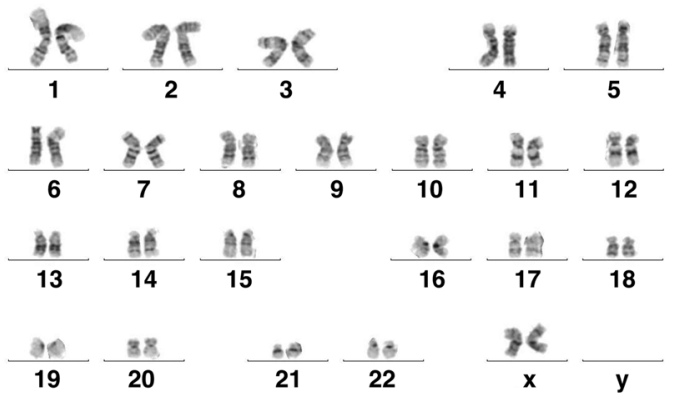

B

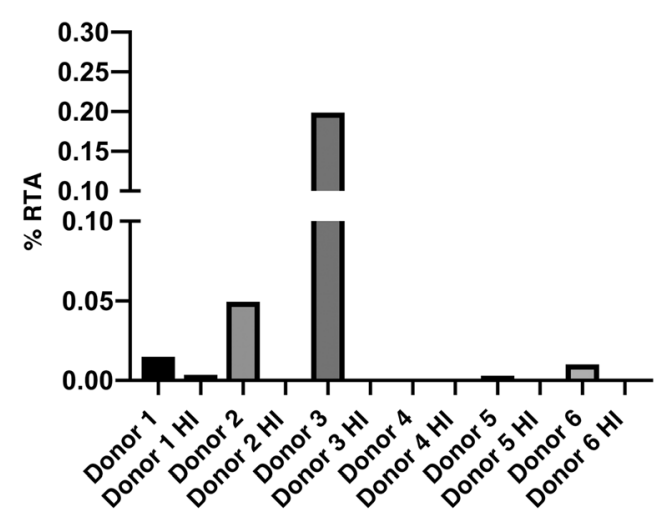

C

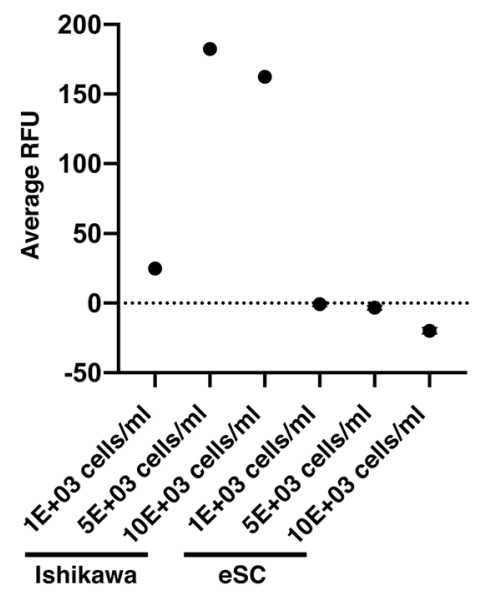

Fig. 3 Endometrial stromal cells (eSCs) are genetically stable and exhibit low tumorigenic potential. a Representative normal karyotype (46,XX) of eSCs at passage (P)3 $(n=4)$. b Bar graph showing percentage relative telomerase activity (RTA), as assessed by quantitative telomeric repeat amplification protocol (qTRAP), in eSCs from each individual donor compared to the Ishikawa cancer cell line $(n=6)$. Heat inactivation $(H I)$ was used as a negative control. c Bar graph of average relative fluorescence units (RFU) quantifying cell number as measurement of eSC and Ishikawa cell anchorage independent growth in a semi-solid agar. eSC data are expressed as mean RFU \pm standard deviation of the mean $(n=5)$

$p<0.0001)$. This suppression was significantly more pronounced in transwell compared to direct cell to cell contact (Fig. $5 \mathrm{a} ; p<0.0001$ ). T cell activation, as assessed by the expression of CD25, was significantly suppressed only within transwell cultures compared to PBMC only controls (Fig. 5b; $p=0.0121$ ). Further analysis on the regulatory $\mathrm{T}$ cell fraction (CD4+CD25+CD127-) suggested no effect by eSCs under either co-culture condition (data not shown).

Exposure of PBMCs to eSCs differentially modulated the status of CD4+ T cells under transwell and direct coculture conditions. The number of CD4+CD27+CD45RAcentral memory (CM) $\mathrm{T}$ cells was significantly reduced only in transwell eSC cultures compared to PBMC only controls (Fig. 5e; $p<0.0001$ ), while the number of CD4+CD27-CD45RA- effector memory (EM) T cells was increased in both direct contact (Fig. 5g; $p=0.0053$ ) and transwell (Fig. 5g; $p=0.0058$ ) eSC co-cultures compared to PBMC only controls. No changes were observed in the CD4+CD27+CD45RA+ naïve and CD4+CD27-CD45RA+ effector memory $\mathrm{T}$ cells re-expressing CD45RA (TEMRA) fractions with eSC exposure (Fig. 5f, h).

\section{Discussion}

The potential for culture-expanded MSC populations, especially bone marrow-derived MSCs, to be utilized as an advanced therapeutic medicinal product in the treatment of numerous disorders has been extensively reported [36]. The breadth of MSC therapy has evolved over the last decade, with a growing interest in the development of cell therapy for fibrotic diseases, such as AS. With new knowledge there has been an overhaul of regulatory requirements for cell therapy, and a growing appreciation that MSCs from different tissue sources possess unique properties as a result of their role in the in vivo niche. The aim of this study was therefore to 

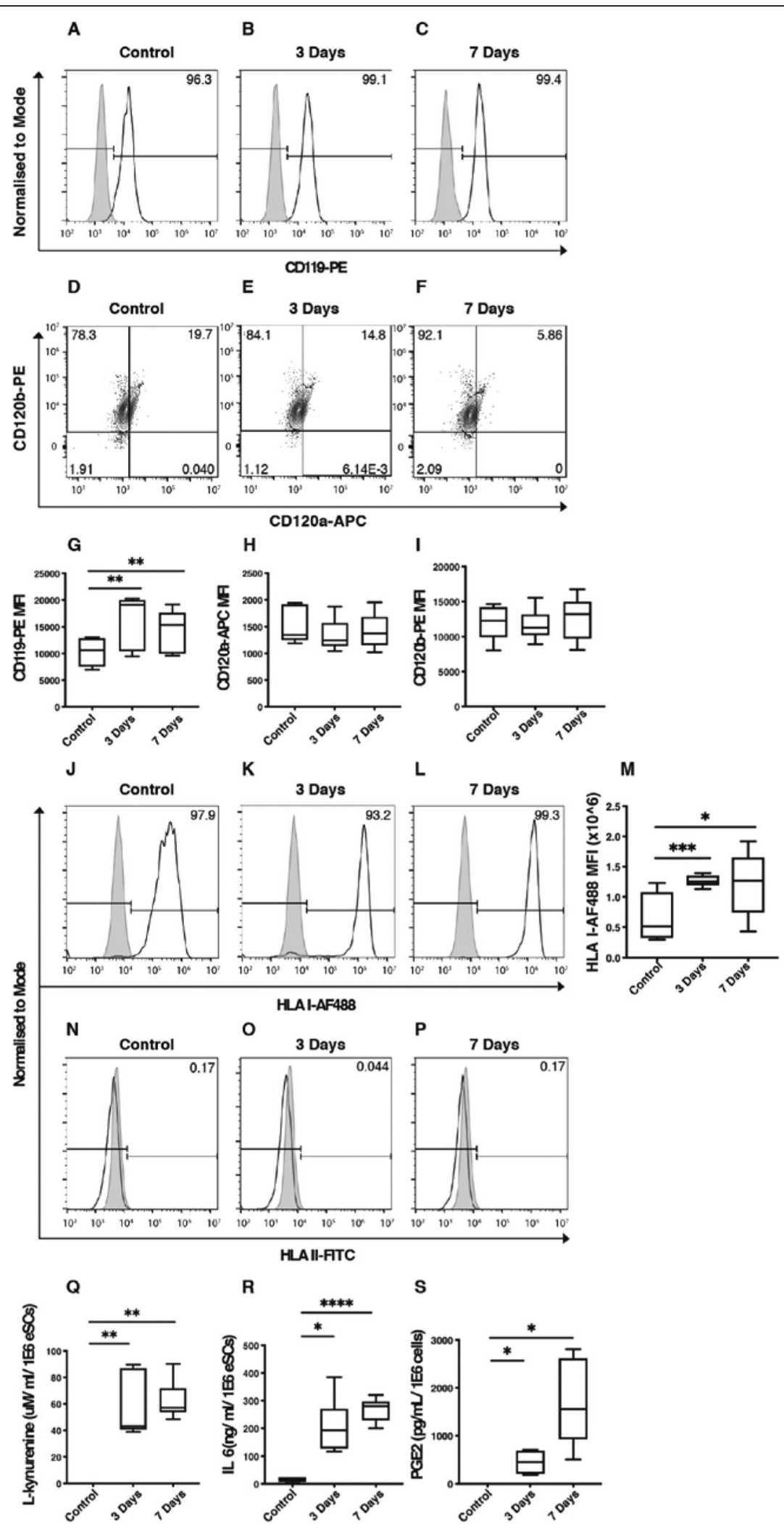

Fig. 4 (See legend on next page.) 


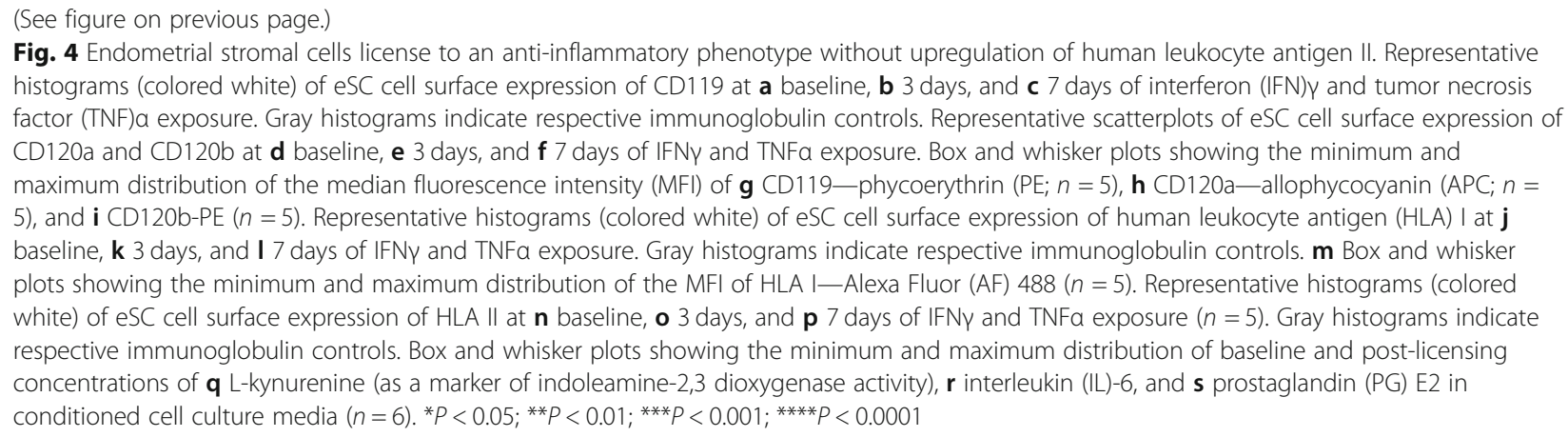

establish protocols for the reliable isolation and expansion of eSCs, and establish their stability and immunomodulatory profiles.

Here we report that isolation and expansion of eSCs from healthy donors are reproducible, generating a stromal population that maintains genetic stability over multiple passages (sufficient to generate a clinical cell dose for local administration to the endometrium), and in keeping with the minimum phenotypic characterization outlined by the ISCT [28]. However, investigation into the responsiveness of these cells to inflammatory stimuli, and their ability to modulate adaptive immune cell subsets, demonstrated distinguishing features, separating eSCs from other adult MSC sources.

Our isolation protocol is a streamlined version of a previous endometrial isolation protocol [37], retaining a heterogeneous stromal compartment, as characterized in recent single-cell sequencing findings [25], which ensures high cell viability with maximum cell retention from pipelle biopsies. Using the ISCT MSC guidelines [28] as a reference to characterize our cell product, we found ex vivo expanded eSCs adhered to plastic; had positive (> 95\%) cell surface marker expression for CD105, CD73, CD90, and HLA I; and lacked expression of hematopoietic surface antigens CD45, CD34, CD14, CD19, and HLA II $(<2 \%)$. As previously reported, eSCs showed multipotent differentiation potential; however, small variations/ predispositions in the degree of differentiation were observed between donors. In line with existing knowledge of the stroma being composed of heterogeneous subpopulations, different proliferation rates, cell morphologies, immunophenotype, and multi-differentiation potential can all be expected [38-41]. This is an important consideration in developing cell therapy products and should be taken into consideration with regard to the expected therapeutic mode of action. Knowledge regarding the potential mode of action of stromal cells in the treatment of endometrial disorders, such as AS, remains scarce, and therefore, we made the informed choice to not narrow down the cell product to a specific subpopulation, e.g., the endometrial pericyte: platelet-derived growth factor receptor beta
(PDGF-R $\beta$ ) $+/$ CD146+ or Sushi Domain Containing 2 (SUSD2)+, as we cautiously cannot exclude that the heterogeneous composition would be part of the therapeutic effect [3, 22, 42, 43].

Isolated eSCs were expanded in xeno-free culture media, with no significant changes in growth rate between P1 and P4; the hypothesized passage ranges for cell therapy being P1-3. Some variability was seen between donors in cumulative PDs at later passages (P4-6), which may be indicative of donor to donor variability. As any product generated will require ex vivo manipulation, in the form of culture expansion, it was important to determine the genetic stability of the eSCs and evaluate the risk of tumorigenicity [44]. Karyotyping our eSCs at P3 showed no chromosomal abnormalities. Likewise, eSCs were unable to show anchorage independent growth in the soft agar colony formation assay and exhibited low telomerase enzyme activity, with no mRNA expression of $h T E R T$, features indicative of tumorigenic cells. Similarly, in a previous study investigating telomerase in the proliferative phase endometrium, activity and gene expression were only localized in the glandular epithelium [45]. This falls in line with the majority of MSC studies that have seen no evidence of genomic instability at early passages [40, 46-48] or tumorigenic potential [48].

In recent years, it has been established that MSCs contribute to tissue regeneration predominantly through the actions of their secretome [18]. Recommendations from ISCT $[29,49]$ have stressed the importance of understanding how stromal cells may reduce inflammation and modulate the innate and adaptive immune systems. Thus, we have studied the responsiveness of the eSCs to pro-inflammatory cytokines to determine the homeostatic state of our cells, and how responsive eSCs are to a pro-inflammatory environment as might be seen in AS. eSCs constitutively expressed the predominant receptor for IFN $\gamma$ (CD119) and TNFa receptor II (CD120b). CD119 expression was upregulated by the presence of proinflammatory cytokines in culture, while expression of $\mathrm{CD} 120 \mathrm{a}$ and $\mathrm{b}$ remained unchanged. 


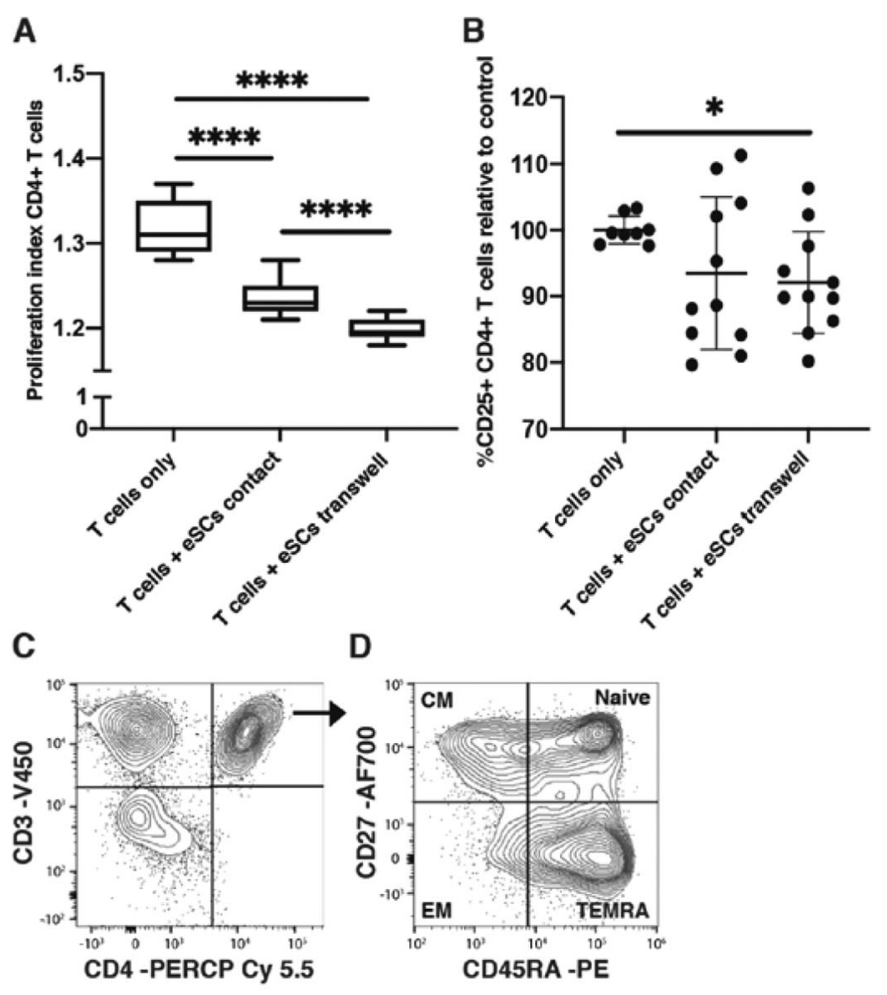

E

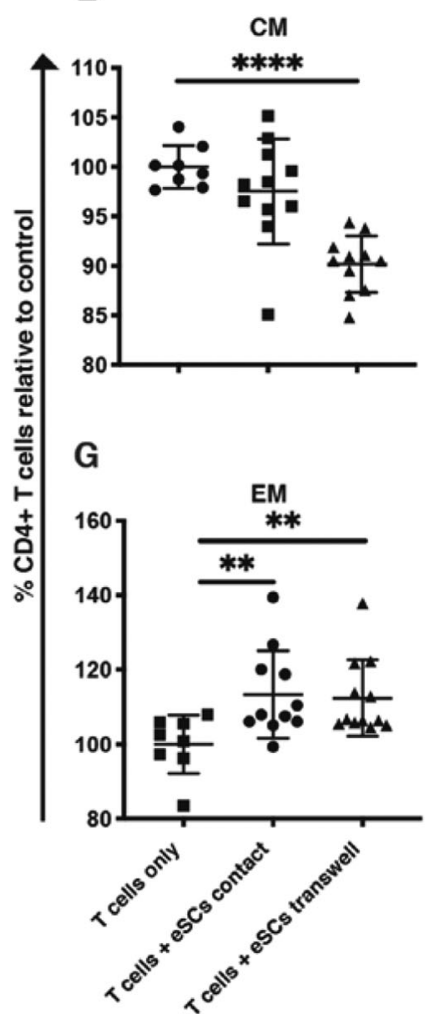

$\mathbf{F}$

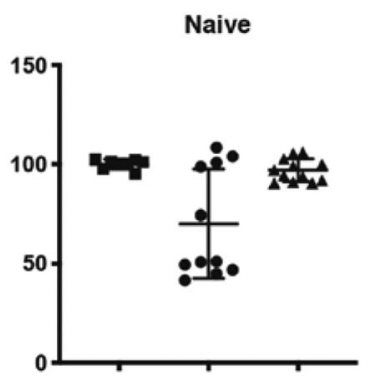

H

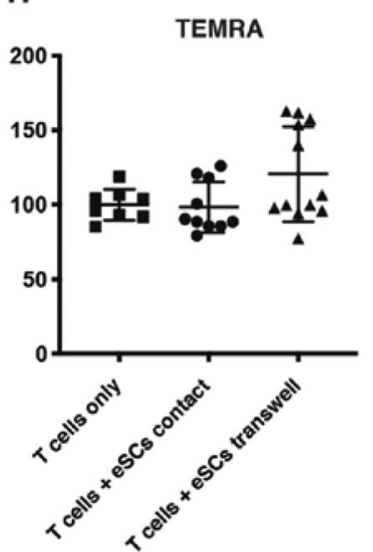

Fig. 5 (See legend on next page.) 


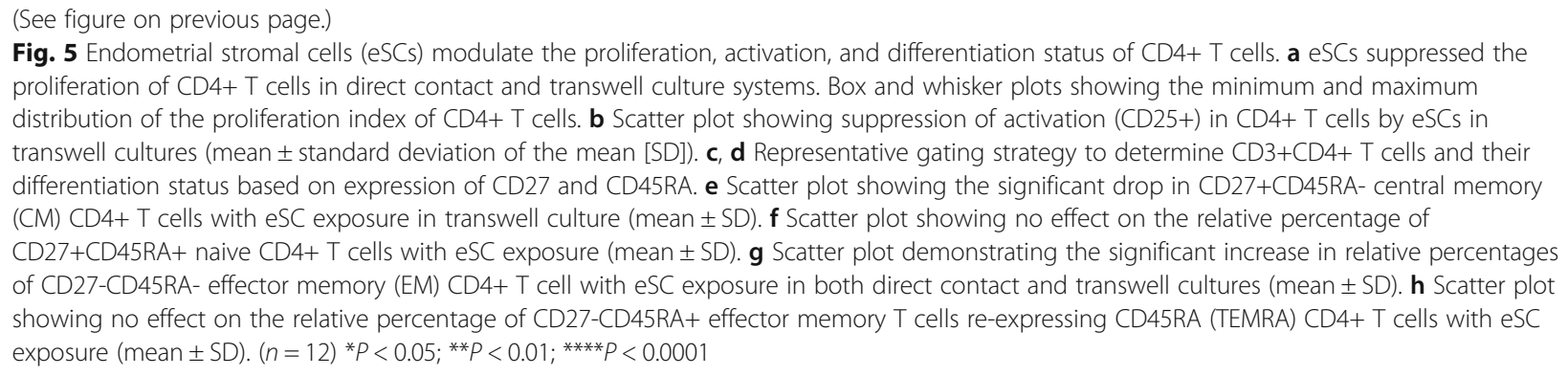

As seen for other MSC sources, IFNY and TNF $\alpha$ licensed the eSCs to an anti-inflammatory state. HLA class I on the surface of the cells was significantly increased, a phenomenon previously demonstrated for both adult and fetal MSCs [34, 50, 51]. In contrast to these reports, eSCs showed no expression of HLA II on the cell surface following 7 days of pro-inflammatory stimulation. These findings demonstrate that eSCs have tissue-specific properties, which have not been previously reported in other cell sources. Embryonic trophoblastic cells have shown a similar immunologic phenotype, and it could be postulated that this mechanism may contribute to fetal-maternal immune tolerance [52]. In the current wave of research into allogeneic induced pluripotent stem cell (iPSC) therapies with HLA I and II knockouts [53], as part of an effort to create a universal iPSC donor, it becomes clear that understanding the translational inactivation of HLA II seen in the endometrium and trophoblast cells could be valuable for many cell therapies, as well as, for transplant tolerance, therefore warranting further investigation at the (epi)genomic level.

Analysis of the eSC secretome demonstrated a switch to an immunomodulatory/suppressive profile, with the production and upregulation of IDO, IL-6, and PGE2 in eSC spent media. This change in secretory profile has been previously reported in other stromal cell populations and is known to mediate the suppression of $\mathrm{T}, \mathrm{NK}$, and dendritic cells [54-56]. Furthermore, the secretion of PGE2 by MSCs has been reported to promote the proliferation of epithelial cells, and therefore, their roles in immunomodulation and healing have been hypothetically linked [57]. Such properties and secretion of key biomolecules lend eSCs to the development of novel cellular therapeutics for endometrial disorders, with elements of both immune and tissue repair dysfunction.

Within the context of the endometrium, the phenotypic profile of the cells may be reflective of the menstrual cycle day at sample collection, suggesting there could be plasticity in the responsiveness of the stroma to differing levels of pro-inflammatory signals dependent on cycle stage. Here biopsies were taken during the proliferative phase, suggesting that significant differences could be seen between this cell source and menSCs.
PGE2, for example, is known to be abundant in the endometrium and regulates vasodilation and edema formation at menstruation [27]. This further highlights the importance of considering CD when taking biopsies for stromal cell isolation.

We further investigated the effects of eSCs and their secretome on the profile of stimulated T cells. As previously reported for MSCs, our results suggest eSCs suppress activated $\mathrm{CD} 4+\mathrm{T}$ cell proliferation via cell-to-cell contact and paracrine factors [58-60]. The overall inhibitory effect being more pronounced in the transwell condition, matching the effect seen by Di Nicola et al. [59]. It has been previously documented that the predominant suppressive effect by MSCs on T cell proliferation occurs through the paracrine effects of PGE2 on monocytes [61]. Furthermore, it has been reported that IL-6, IDO, and PGE2 secreted by MSCs can skew both peripheral monocytes and tissue-resident macrophages to an M2, anti-inflammatory phenotype with elevated secretion of IL-10 [56, 62, 63]. Monocytes constitute around $10 \%$ of the PBMC fraction, and therefore, the induction of suppression by the eSCs may be an indirect effect through the monocyte population. In contrast, a suppression in the activation state of CD4+ T cells was only seen by the eSC secretome. This may be indicative of additional immunomodulatory pathways, including that of programmed cell death protein 1 (PD-1):PD-ligand(L)1/ PD-L2 axis, demonstrated to directly regulate T cell CD25 expression by the bone marrow MSC secretome [32].

eSCs primarily elicited a decrease in CM T cells under eSC transwell co-culturing conditions and an increase in the relative expression of EM T cells in transwell and cell-to-cell contact co-culture conditions. MSCs derived from similar fetal/ maternal tissue, i.e., placenta and amniotic fluid, also significantly decrease memory $\mathrm{T}$ cell subsets, yet also induce an increase in naïve $\mathrm{T}$ cells, an effect we did not see in our co-culture models [64]. MSCs derived from other origins have been shown to suppress $\mathrm{CM}$ and $\mathrm{EM} \mathrm{CD} 4+\mathrm{T}$ cell differentiation and cytokine production, inducing a more immune tolerant profile [65-67]. Interestingly, it has been reported that IL-10 decreases both CM and EM development specifically within the $\mathrm{CD} 4+\mathrm{T}$ cell compartment in response to 
viral infection [68]. The notion that we see an increase in EM T cells may be a link to their in vivo role. EM T cells are characterized by their lack of $\mathrm{C}-\mathrm{C}$ chemokine receptor (CCR)7 expression, meaning that they are primed to leave the circulation and enter inflamed tissue to participate in reparative responses [69]. As EM T cells are the first line of defense against reinfection [70], with privileged access to tissue sites vulnerable to pathogens, such as the endometrium, it is not surprising that eSCs possess a directed response to this immune subset on seeing inflammation.

\section{Conclusions}

In conclusion, we demonstrate that eSCs can be reproducibly isolated and expanded in vitro, with maintenance of genetic stability. eSCs, despite initial similarities to MSCs as defined by the ISCT, exhibit distinct differences in phenotype and function, in particular their mode of immunomodulatory action and HLA II expression, which are most likely adapted to suit the microenvironment of the endometrium. These findings warrant further investigation to establish their mode of immunomodulatory action and potential for therapeutic development in the treatment of endometrial disorders, such as AS.

\section{Supplementary information}

Supplementary information accompanies this paper at https://doi.org/10. 1186/s13287-019-1496-2.

Additional file 1: Figure S1. Confirmation of endometrial stromal cell potential. eSCs were subjected to osteogenic or adipogenic differentiation by culturing with induction or control medium. Osteogenic differentiation was detected by staining mineralized matrix with Alizarin Red. Representative photomicrographs of A) control, scale bar $=200 \mu \mathrm{m}$ and B) induced cultures, scale bar $=200 \mu \mathrm{m}$. Adipogenic differentiation was detected by Oil red $\mathrm{O}$ staining of lipid rich vacuoles. Representative photomicrographs of C) control, scale bar $=100 \mu \mathrm{m}$ and D) induced cultures, scale bar $=100 \mu \mathrm{m}(n=6)$

\footnotetext{
Abbreviations

AF: Alexa Fluor; APC: Allophycocyanin; AS: Asherman's syndrome; BSA: Bovine serum albumin; CCR: C-C chemokine receptor; CD: Cycle day; CFU-F: Colony-forming unit-fibroblasts; CM: Central memory; ELISA: Enzymelinked immunosorbent assay; EM: Effector memory; eSC: Endometrial stromal cell; FITC: Fluorescein isothiocyanate; HLA: Human leukocyte antigen; IDO: Indoleamine 2,3-dioxygenase; IFNY (R): Interferon gamma (receptor); IL: Interleukin; iPSC: Induced pluripotent stem cell; ISCT: International Society for Cellular Therapy; MEMa: Minimum Essential Medium Eagle - Alpha Modification; MenSCs: Menstrual blood-derived stromal cells; MFI: Median fluorescence intensity; MSC: Mesenchymal stromal cell; P: Passage; PB: Pacific blue; PBMC: Peripheral blood mononuclear cells; PBS: Phosphate buffered saline; PD: Population doubling; PD-1: Programmed cell death protein 1; PDGFR: Platelet-derived growth factor receptor; PD-L: Programmed cell death protein 1 ligand; PE: Phycoerythrin; PerCP Cy5.5: Peridinin chlorophyll protein; PGE2: Prostaglandin E2; qPCR: Quantitative real-time polymerase chain reaction; qTRAP: Quantitative Telomeric Repeat Amplification Protocol; RFU: Relative fluorescence unit; RPMI: Roswell Park Memorial Institute; RTA: Relative telomerase activity; SUSD2: Sushi Domain Containing 2; TEMRA: Effector memory T cells re-expressing CD45RA; TNFa: Tumor necrosis factor alpha; UC MSC: Umbilical cord-derived MSC
}

\section{Acknowledgements}

The authors would like to acknowledge all staff at the WHO collaborating center for research and research training in human reproduction at Karolinska Institutet and Karolinska University Hospital for helping in collecting biopsies, and the healthy women who participated in this study. Open access funding provided by Karolinska Institute.

\section{Authors' contributions}

SQ designed the study, conducted the experiments, analyzed the data, interpreted the data, wrote the manuscript, and provided approval for the final version of the manuscript. ESL conducted the karyotyping and interpreted the data and provided approval for the final version of the manuscript. KGD designed the study, recruited patients, collected biopsies, wrote the manuscript, and provided approval for the final version of the manuscript. LCD designed the study, conducted experiments, interpreted the data, wrote the manuscript, and provided approval for the final version of the manuscript.

\section{Funding}

The authors acknowledge funding from Jane and Dan Olsson Foundation, The Swedish research council (2017-00932), Karolinska Institutet (KID) (2-3591/2014).

\section{Availability of data and materials}

All data generated or analyzed during this study are included in this published article.

\section{Ethics approval and consent to participate}

The study was approved by the regional ethics committee of Karolinska Institutet, Stockholm, Sweden, and conducted in line with the Helsinki Declaration (ethical approval reference numbers DNR: 2015/367-31/4 and 2017/216-31). Written informed consent was obtained from all participating women.

\section{Consent for publication}

Not applicable.

\section{Competing interests}

The authors declare that they have no competing interests.

\section{Author details}

${ }^{1}$ Department of Women's and Children's Health, Division of Obstetrics and Gynecology, Karolinska Institutet, and Karolinska University Hospital, S-171 64 Solna, Sweden. ${ }^{2}$ Department of Clinical Genetics, Karolinska University Hospital, S-171 76 Stockholm, Sweden. ${ }^{3}$ Department of Laboratory Medicine, Karolinska Institutet, S-141 52 Huddinge, Sweden.

Received: 7 August 2019 Revised: 4 November 2019

Accepted: 15 November 2019 Published online: 06 January 2020

\section{References}

1. Chavez-MacGregor M, van Gils CH, van der Schouw YT, Monninkhof E, van Noord PA, Peeters PH. Lifetime cumulative number of menstrual cycles and serum sex hormone levels in postmenopausal women. Breast Cancer Res Treat. 2008;108(1):101-12.

2. Chan RW, Schwab KE, Gargett CE. Clonogenicity of human endometrial epithelial and stromal cells. Biol Reprod. 2004;70(6):1738-50.

3. Schwab KE, Gargett CE. Co-expression of two perivascular cell markers isolates mesenchymal stem-like cells from human endometrium. Human Reproduction. 2007:22(11):2903-11.

4. Yu D, Wong YM, Cheong Y, Xia E, Li TC. Asherman syndrome--one century later. Fertil Steril. 2008;89(4):759-79.

5. Finn CA. Implantation, menstruation and inflammation. Biol Rev. 1986;61(4): 313-28.

6. Salamonsen LA. Tissue injury and repair in the female human reproductive tract. Reproduction. 2003;125(3):301-11.

7. Jabbour HN, Kelly RW, Fraser HM, Critchley HO. Endocrine regulation of menstruation. Endocr Rev. 2006;27(1):17-46.

8. Reinke JM, Sorg H. Wound repair and regeneration. Eur Surg Res. 2012;49(1): 35-43.

9. Larson BJ, Longaker MT, Lorenz HP. Scarless fetal wound healing: a basic science review. Plast Reconstr Surg. 2010;126(4):1172-80. 
10. Maybin J, Critchley H. Repair and regeneration of the human endometrium. Expert Review Obstetrics Gynecol. 2009;4(3):283-98.

11. Peake MA, Caley M, Giles PJ, Wall I, Enoch S, Davies LC, et al. Identification of a transcriptional signature for the wound healing continuum. Wound Repair Regen. 2014;22(3):399-405.

12. Davies LC, Locke M, Webb RD, Roberts JT, Langley M, Thomas DW, et al. A multipotent neural crest-derived progenitor cell population is resident within the oral mucosa lamina propria. Stem Cells Dev. 2010;19(6):819-30.

13. Maybin JA, Critchley HO. Menstrual physiology: implications for endometrial pathology and beyond. Hum Reprod Update. 2015;21(6):748-61

14. Kelly RW, Illingworth P, Baldie G, Leask R, Brouwer S, Calder AA. Progesterone control of interleukin-8 production in endometrium and chorio-decidual cells underlines the role of the neutrophil in menstruation and parturition. Human Reproduction (Oxford, England). 1994;9(2):253-8.

15. Hornung D, Ryan IP, Chao VA, Vigne JL, Schriock ED, Taylor RN. Immunolocalization and regulation of the chemokine RANTES in human endometrial and endometriosis tissues and cells. J Clin Endocrinol Metab. 1997;82(5):1621-8

16. Gargett CE, Lederman F, Heryanto B, Gambino LS, Rogers PA. Focal vascular endothelial growth factor correlates with angiogenesis in human endometrium. Role of intravascular neutrophils. Human Reproduction. 2001; 16(6):1065-75

17. Flynn L, Byrne B, Carton J, Kelehan P, O'Herlihy C, O'Farrelly C. Menstrual cycle dependent fluctuations in NK and T-lymphocyte subsets from nonpregnant human endometrium. Am J Reprod Immunol. 2000;43(4):209-17.

18. Caplan AI. Why are MSCs therapeutic? New data: new insight. J Pathol. 2009;217(2):318-24.

19. Cervello I, Gil-Sanchis C, Santamaria X, Cabanillas S, Diaz A, Faus A, et al. Human CD133(+) bone marrow-derived stem cells promote endometrial proliferation in a murine model of Asherman syndrome. Fertility Sterility. 2015;104(6):1552-60 e1-3.

20. Santamaria X, Cabanillas S, Cervello I, Arbona C, Raga F, Ferro J, et al. Autologous cell therapy with CD133+ bone marrow-derived stem cells for refractory Asherman's syndrome and endometrial atrophy: a pilot cohort study. Human Reproduction. 2016;31(5):1087-96.

21. Tan J, Li P, Wang Q, Li Y, Li X, Zhao D, et al. Autologous menstrual bloodderived stromal cells transplantation for severe Asherman's syndrome. Human Reproduction. 2016;31(12):2723-9.

22. Gurung S, Deane JA, Darzi S, Werkmeister JA, Gargett CE. In vivo survival of human endometrial mesenchymal stem cells transplanted under the kidney capsule of immunocompromised mice. Stem Cells Dev. 2018;27(1):35-43.

23. Queckborner S, Davies LC, von Grothusen C, Santamaria X, Simon C, Gemzell-Danielsson K. Cellular therapies for the endometrium: an update. Acta Obstet Gynecol Scand. 2019;98(5):672-7.

24. Cao Y, Sun H, Zhu H, Zhu X, Tang X, Yan G, et al. Allogeneic cell therapy using umbilical cord MSCs on collagen scaffolds for patients with recurrent uterine adhesion: a phase I clinical trial. Stem Cell Res Ther. 2018:9(1):192.

25. Vento-Tormo R, Efremova M, Botting RA, Turco MY, Vento-Tormo M, Meyer $\mathrm{KB}$, et al. Single-cell reconstruction of the early maternal-fetal interface in humans. Nature. 2018;563(7731):347-53.

26. Critchley $H$, Jones R, Lea R, Drudy T, Kelly R, Williams A, et al. Role of inflammatory mediators in human endometrium during progesterone withdrawal and early pregnancy. J Clin Endocrinol Metab. 1999;84:240-8.

27. Critchley H, Kelly R, Brenner R, Baird D. The endocrinology of menstruation - a role for the immune system. Clin Endocrinol. 2001;55:701-10.

28. Dominici M, Le Blanc K, Mueller I, Slaper-Cortenbach I, Marini F, Krause D, et al. Minimal criteria for defining multipotent mesenchymal stromal cells. The International Society for Cellular Therapy position statement. Cytotherapy. 2006:8(4):315-7.

29. Krampera M, Galipeau J, Shi Y, Tarte K, Sensebe L. Immunological characterization of multipotent mesenchymal stromal cells-the International Society for Cellular Therapy (ISCT) working proposal. Cytotherapy. 2013;15(9):1054-61.

30. Friedenstein AJ, Chailakhyan RK, Latsinik NV, Panasyuk AF, Keiliss-Borok IV. Stromal cells responsible for transferring the microenvironment of the hemopoietic tissues. Cloning in vitro and retransplantation in vivo. Transplantation. 1974;17(4):331-40.

31. Ujvari D, Jakson I, Babayeva S, Salamon D, Rethi B, Gidlof S, et al. Dysregulation of in vitro decidualization of human endometrial stromal cells by insulin via transcriptional inhibition of forkhead box protein 01. PLoS One. 2017;12(1):e0171004.
32. Davies LC, Heldring N, Kadri N, Le Blanc K. Mesenchymal stromal cell secretion of programmed death-1 ligands regulates T cell mediated immunosuppression. Stem Cells. 2017;35(3):766-76.

33. Mahanonda R, Sa-Ard-lam N, Montreekachon P, Pimkhaokham A, Yongvanichit K, Fukuda MM, et al. IL-8 and IDO expression by human gingival fibroblasts via TLRs. J Immunol. 2007;178(2):1151-7.

34. Davies LC, Lonnies H, Locke M, Sundberg B, Rosendahl K, Gotherstrom C, et al. Oral mucosal progenitor cells are potently immunosuppressive in a dose-independent manner. Stem Cells Dev. 2012;21(9):1478-87.

35. Ponandai-Srinivasan S, Andersson KL, Nister M, Saare M, Hassan HA, Varghese SJ, et al. Aberrant expression of genes associated with stemness and cancer in endometria and endometrioma in a subset of women with endometriosis. Human Reproduction. 2018:33(10):1924-38.

36. Le Blanc K, Frassoni F, Ball L, Locatelli F, Roelofs H, Lewis I, et al. Mesenchymal stem cells for treatment of steroid-resistant, severe, acute graft-versus-host disease: a phase II study. Lancet. 2008;371(9624):1579-86.

37. Berger C, Boggavarapu NR, Menezes J, Lalitkumar PG, Gemzell-Danielsson K. Effects of ulipristal acetate on human embryo attachment and endometrial cell gene expression in an in vitro co-culture system. Human Reproduction. 2015;30(4):800-11.

38. Schellenberg A, Stiehl T, Horn P, Joussen S, Pallua N, Ho AD, et al. Population dynamics of mesenchymal stromal cells during culture expansion. Cytotherapy. 2012;14(4):401-11.

39. Russell KC, Phinney DG, Lacey MR, Barrilleaux BL, Meyertholen KE, O'Connor KC. In vitro high-capacity assay to quantify the clonal heterogeneity in trilineage potential of mesenchymal stem cells reveals a complex hierarchy of lineage commitment. Stem Cells. 2010;28(4):788-98.

40. Martin I, De Boer J, Sensebe L. A relativity concept in mesenchymal stromal cell manufacturing. Cytotherapy. 2016;18(5):613-20.

41. Trivedi A, Miyazawa B, Gibb S, Valanoski K, Vivona L, Lin M, et al. Bone marrow donor selection and characterization of MSCs is critical for preclinical and clinical cell dose production. J Transl Med. 2019:17(1):128.

42. Schüring AN, Schulte N, Kelsch R, Röpke A, Kiesel L, Götte M. Characterization of endometrial mesenchymal stem-like cells obtained by endometrial biopsy during routine diagnostics. Fertility Sterility. 95(1):423-6.

43. Spitzer TL, Rojas A, Zelenko Z, Aghajanova L, Erikson DW, Barragan F, et al. Perivascular human endometrial mesenchymal stem cells express pathways relevant to self-renewal, lineage specification, and functional phenotype. Biol Reprod. 2012;86(2):58.

44. Barkholt L, Flory E, Jekerle V, Lucas-Samuel S, Ahnert P, Bisset L, et al. Risk of tumorigenicity in mesenchymal stromal cell-based therapies--bridging scientific observations and regulatory viewpoints. Cytotherapy. 2013;15(7):753-9.

45. Tanaka M, Kyo S, Takakura M, Kanaya T, Sagawa T, Yamashita K, et al. Expression of telomerase activity in human endometrium is localized to epithelial glandular cells and regulated in a menstrual phase-dependent manner correlated with cell proliferation. Am J Pathol. 1998;153(6):1985-91.

46. Sensebé L, Tarte K, Galipeau J, Krampera M, Martin I, Phinney Donald G, et al. Limited acquisition of chromosomal aberrations in human adult mesenchymal stromal cells. Cell Stem Cell. 2012;10(1):9-10.

47. Guess AJ, Daneault B, Wang R, Bradbury H, La Perle KMD, Fitch J, et al. Safety profile of good manufacturing practice manufactured interferon gamma-primed mesenchymal stem/stromal cells for clinical trials. Stem Cells Transl Med. 2017:6(10):1868-79.

48. Tarte K, Gaillard J, Lataillade J-J, Fouillard L, Becker M, Mossafa H, et al. Clinical-grade production of human mesenchymal stromal cells: occurrence of aneuploidy without transformation. Blood. 2010;115(8):1549-53.

49. Galipeau J, Krampera M, Barrett J, Dazzi F, Deans RJ, DeBruijn J, et al. International Society for Cellular Therapy perspective on immune functional assays for mesenchymal stromal cells as potency release criterion for advanced phase clinical trials. Cytotherapy. 2016;18(2):151-9.

50. Gotherstrom C, Ringden O, Westgren M, Tammik C, Le Blanc K. Immunomodulatory effects of human foetal liver-derived mesenchymal stem cells. Bone Marrow Transplant. 2003;32(3):265-72.

51. Le Blanc K, Tammik C, Rosendahl K, Zetterberg E, Ringden O. HLA expression and immunologic properties of differentiated and undifferentiated mesenchymal stem cells. Exp Hematol. 2003;31(10):890-6.

52. Murphy SP, Tomasi TB. Absence of MHC class $\|$ antigen expression in trophoblast cells results from a lack of class II transactivator (CIITA) gene expression. Mol Reprod Dev. 1998;51(1):1-12.

53. Deuse T, Hu X, Gravina A, Wang D, Tediashvili G, De C, et al. Hypoimmunogenic derivatives of induced pluripotent stem cells evade 
immune rejection in fully immunocompetent allogeneic recipients. Nat Biotechnol. 2019;37(3):252-8.

54. Djouad F, Charbonnier LM, Bouffi C, Louis-Plence P, Bony C, Apparailly F, et al. Mesenchymal stem cells inhibit the differentiation of dendritic cells through an interleukin-6-dependent mechanism. Stem Cells. 2007;25(8): 2025-32.

55. Meisel R, Zibert A, Laryea M, Gobel U, Daubener W, Dilloo D. Human bone marrow stromal cells inhibit allogeneic T-cell responses by indoleamine 2,3dioxygenase-mediated tryptophan degradation. Blood. 2004;103(12):4619-21.

56. Nemeth K, Leelahavanichkul A, Yuen PS, Mayer B, Parmelee A, Doi K, et al. Bone marrow stromal cells attenuate sepsis via prostaglandin $E(2)$ dependent reprogramming of host macrophages to increase their interleukin-10 production. Nat Med. 2009;15(1):42-9.

57. Le Blanc K, Mougiakakos D. Multipotent mesenchymal stromal cells and the innate immune system. Nat Rev Immunol. 2012;12(5):383-96.

58. Duffy MM, Ritter T, Ceredig R, Griffin MD. Mesenchymal stem cell effects on T-cell effector pathways. Stem Cell Res Ther. 2011;2(4):34.

59. Di Nicola M, Carlo-Stella C, Magni M, Milanesi M, Longoni PD, Matteucci P, et al. Human bone marrow stromal cells suppress T-lymphocyte proliferation induced by cellular or nonspecific mitogenic stimuli. Blood. 2002;99(10):3838-43.

60. Bartholomew A, Sturgeon C, Siatskas M, Ferrer K, Mclntosh K, Patil S, et al. Mesenchymal stem cells suppress lymphocyte proliferation in vitro and prolong skin graft survival in vivo. Exp Hematol. 2002;30(1):42-8.

61. Cutler AJ, Limbani V, Girdlestone J, Navarrete CV. Umbilical cord-derived mesenchymal stromal cells modulate monocyte function to suppress $\mathrm{T}$ cell proliferation. J Immunol. 2010;185(11):6617-23.

62. Melief SM, Geutskens SB, Fibbe WE, Roelofs H. Multipotent stromal cells skew monocytes towards an anti-inflammatory interleukin-10-producing phenotype by production of interleukin-6. Haematologica. 2013;98(6):888-95.

63. Francois M, Romieu-Mourez R, Li M, Galipeau J. Human MSC suppression correlates with cytokine induction of indoleamine 2,3-dioxygenase and bystander M2 macrophage differentiation. Mol Ther. 2012;20(1):187-95.

64. Mareschi K, Castiglia S, Sanavio F, Rustichelli D, Muraro M, Defedele D, et al. Immunoregulatory effects on T lymphocytes by human mesenchymal stromal cells isolated from bone marrow, amniotic fluid, and placenta. Exp Hematol. 2016;44(2):138-50 e1.

65. Krampera M, Glennie S, Dyson J, Scott D, Laylor R, Simpson E, et al. Bone marrow mesenchymal stem cells inhibit the response of naive and memory antigen-specific T cells to their cognate peptide. Blood. 2003;101(9):3722-9.

66. Reading JL, Yang JH, Sabbah S, Skowera A, Knight RR, Pinxteren J, et al. Clinical-grade multipotent adult progenitor cells durably control pathogenic T cell responses in human models of transplantation and autoimmunity. J Immunol. 2013;190(9):4542-52.

67. Laranjeira P, Pedrosa M, Pedreiro S, Gomes J, Martinho A, Antunes B, et al. Effect of human bone marrow mesenchymal stromal cells on cytokine production by peripheral blood naive, memory, and effector T cells. Stem Cell Res Ther. 2015;6(1):3.

68. Brooks DG, Walsh KB, Elsaesser H, Oldstone MB. IL-10 directly suppresses CD4 but not CD8 T cell effector and memory responses following acute viral infection. Proc Natl Acad Sci U S A. 2010;107(7):3018-23.

69. Sallusto F, Lenig D, Forster R, Lipp M, Lanzavecchia A. Two subsets of memory T lymphocytes with distinct homing potentials and effector functions. Nature. 1999;401(6754):708-12.

70. Gebhardt T, Wakim LM, Eidsmo L, Reading PC, Heath WR, Carbone FR. Memory $T$ cells in nonlymphoid tissue that provide enhanced local immunity during infection with herpes simplex virus. Nat Immunol. 2009; 10(5):524-30.

\section{Publisher's Note}

Springer Nature remains neutral with regard to jurisdictional claims in published maps and institutional affiliations.

Ready to submit your research? Choose BMC and benefit from:

- fast, convenient online submission

- thorough peer review by experienced researchers in your field

- rapid publication on acceptance

- support for research data, including large and complex data types

- gold Open Access which fosters wider collaboration and increased citations

- maximum visibility for your research: over $100 \mathrm{M}$ website views per year

At BMC, research is always in progress.

Learn more biomedcentral.com/submissions 